\title{
CONSULTATION SKILLS FOR RESOURCE TEACHERS
}

\begin{abstract}
Although the importance of the resource teacher's consulting role has been widely acknowledged, relatively little information is available on educators' perceptions of that role. This study was undertaken to identify the consulting skills educators expect resource teachers to possess, and to determine how proficiently resource teachers are judged to perform the consultant role. Based on the responses of resource teachers, regular education teachers, and principals to a questionnaire, most of the skills typically associated with consultation were determined to be necessary for resource teachers. In addition, resource teachers were rated moderately skilled as consultants. These results suggest that educators' expectations for resource teachers' job performance may be unrealistic, and that consultation may be an area in which skill development for resource teachers is needed.
\end{abstract}

The importance of consultation in resource room programs has been increasingly recognized. Thus, the provision of indirect services to mainstreamed pupils through professional interactions with their regular education teachers and others is now frequently identified as an essential complement to the direct services resource teachers have traditionally provided (Elman \& Ginsberg, 1981; Heron \& Harris, 1982; McLoughlin \& Kelly, 1982). For example, guidelines for the successful establishment and operation of resource room programs invariably include statements about the necessity of providing consultative services to other school personnel and parents (Cohen, 1982; Hawisher \& Calhoun, 1978; Paroz, Siegenthaler, \& Tatum, 1977; Wiederholt, Hammill, \& Brown, 1983). Likewise, investigations of resource teachers' perceptions of their responsibilities (Brown, Kiraly, \& McKinnon, 1979; Summers, 1978) and regular classroom teachers' preferences for support services for mainstreamed students (Hudson, Graham, \& Warner, 1979; Gickling, Murphy, \& Mallory, 1979) indicate that consulting is a desired and expected resource teacher role.

Despite agreement on the necessity of con- sultation, only a few investigators have examined educators' perceptions of this aspect of resource teaching. For example, Brown et al. (1979) found that although the resource teachers they surveyed believed communication with regular educators was important, paperwork and scheduling problems were reported to severely limit such exchanges. Similarly, Evans (1980, 1981) interviewed school personnel about consultation, and found that resource teachers, regular education teachers and principals believed the time resource teachers devote to consultation should be increased. However, the resource teachers felt inadequately prepared to function as consultants. ats. In an observational study, Sargent (1981) reported that $8.5 \%$ of resource teachers' time was spent "consulting" with other teachers. Anecdotally, however, it was noted that most of these interactions concerned school business, not mainstreamed pupils. These fragments of information suggest

MARILYN FRIEND, Ph.D., is Assistant Professor, Dept. of Special Education, University of Oklahoma. 
that educators recognize the complexity of consultation and the potential difficulties resource teachers may encounter carrying out that role.

This study was undertaken to describe in greater detail resource teachers', regular education classroom teachers', and principals' perceptions of consultation as a resource teacher responsibility. Specifically, the purposes of the study were to determine (a) which skills typically associated with consultation educators believe should constitute part of the resource teacher's repertoire, (b) how proficient resource teachers are judged to be as consultants, and (c) whether the three groups of educators concur in their perceptions.

\section{Participants}

\section{METHOD}

A stratified sample of three school districts and four special education cooperatives (serving an additional 27 districts) was selected to represent the geographic regions and population distribution of Indiana. All the school districts enrolled learning disabled students in their resource room programs, many of which also served mildly retarded and emotionally disturbed pupils.

Three groups of educators comprised the sample. In addition to asking all the school districts' resource teachers $(\mathrm{N}=173)$ to participate in the study, 217 randomly selected regular education teachers were included. This number represented one teacher for each resource room in the cooperating school districts. ${ }^{1}$ Finally, the participation of the principals of all schools with one or more resource rooms $(\mathrm{N}=195)$ was sought.

A total of 150 resource teachers, 194 regular education teachers, and 176 principals completed the survey instrument $189 \%$ response rate). Of these, $71 \%$ were assigned to elementary schools, $18 \%$ taught in middle schools or junior highs, and $11 \%$ taught in high schools.

\section{Instrumentation and Procedure}

As part of a survey instrument designed to gather information on various aspects of resource teacher consultation, 17 statements were developed to describe the consultation skills and activities which might be considered appropriate for resource teachers (see Table 1). The content of the statements was derived from a review of special education, counseling, and educational psychology literature, as well as a preliminary investigation of resource teachers' perceptions of their consultative duties.

Respondents evaluated each statement in two ways. On the first scale, resource teachers indicated whether or not the described skill was one they should have, while the regular education teachers and principals indicated whether or not resource teachers as a professional group should have the skill. On the second scale, resource teachers responded to the statements in terms of their own proficiency by rating themselves on each statement on a 5-point scale ( $1=$ little skill, $3=$ moderate skill, and $5=$ much skill). The other two groups of subjects used the same rating procedure to evaluate the consultation proficiencies of the resource teachers with whom they had interacted.

The questionnaires were delivered to school principals who were asked to distribute them to the teachers designated in an accompanying cover letter. The surveys were collected one week after their distribution. Telephone reminders were used as a follow-up procedure to maximize the response rate.

\section{Consultation Skills Needed by Resource Teachers}

For each of the 17 statements describing consulting responsibilities, the percentage of the total sample agreeing that the skill was one resource teachers should possess was calculated. As indicated by the numbers in parentheses after the statements in Table 1, a large majority of the educators perceived all skills to be necessary. The greatest consensus was obtained on the item concerning systematically evaluating attempted interventions $(96.7 \%)$, whereas the statement about conducting inservice training received the fewest positive responses $(79.5 \%)$.

\section{Resource Teacher Consultation Proficiency}

The responses from 126 triads, each consisting of a resource teacher, a regular education teacher, and a principal from a single school, were used to examine educators' ratings of resource teacher consultation proficiency. By making this adjustment in the sample, it was possible to ensure that no school was over- or underrepresented in the analyses.

These data were analyzed in two ways. First, educators' responses were summed and treated as a single global measure of perceived proficiency. In addition, responses to each item were examined separately. A repeated-measures ANOVA, with 
TABLE 1

Educators' Ratings of Resource Teacher Consultation Proficiency

\begin{tabular}{|c|c|c|c|c|}
\hline Consultation Skill/Activity ${ }^{\mathrm{a}}$ & $\begin{array}{c}\text { Resource } \\
\text { Teachers } \\
(\mathrm{N}=126)\end{array}$ & $\begin{array}{l}\text { Reg. Ed. } \\
\text { Teachers } \\
(\mathrm{N}=126)\end{array}$ & $\begin{array}{l}\text { Principals } \\
(N=126)\end{array}$ & $\begin{array}{c}F \\
(2,250)\end{array}$ \\
\hline $\begin{array}{l}\text { Systematically evaluating interventions to determine } \\
\text { effectiveness }(96.7)^{b}\end{array}$ & $3.51^{\mathrm{c}}$ & 3.13 & 3.47 & $5.570^{\circ}$ \\
\hline Establishing a climate of mutual tust (95.9) & 4.20 & 3.95 & 4.04 & 2.265 \\
\hline $\begin{array}{l}\text { Explaining resource teacher perception of a problem } \\
\text { stuation to a regular education teacher }(95.9)\end{array}$ & 3.96 & 3.45 & 3.53 & $9.244^{*}$ \\
\hline $\begin{array}{l}\text { Explicitly defining the problems resource teachers and } \\
\text { regular education teachers address }(95.7)\end{array}$ & 3.40 & 3.32 & 3.44 & .402 \\
\hline $\begin{array}{l}\text { Interviewing regular education teachers to obtain } \\
\text { academic, social, and behavioral information about a stu- } \\
\text { dent (95.5) }\end{array}$ & 3.82 & 3.72 & 3.80 & 1.052 \\
\hline $\begin{array}{l}\text { "Brainstorming" to generate possible solutions to a } \\
\text { child's regular classroom academic/social problems (94.7) }\end{array}$ & 3.67 & 3.44 & 3.51 & 1.793 \\
\hline $\begin{array}{l}\text { Assisting regular education teachers in identifying } \\
\text { potential positive/ negative consequences of planned in- } \\
\text { terventions }(92.6)\end{array}$ & 3.30 & 3.18 & 3.33 & 691 \\
\hline $\begin{array}{l}\text { Regularty scheduling conferences with regular education } \\
\text { teachers to discuss shared students (91.8) }\end{array}$ & 3.29 & 2.88 & 3.36 & $5.581^{\bullet}$ \\
\hline $\begin{array}{l}\text { Functioning as a "resource linker" between regular educa- } \\
\text { tion teachers and other individuals/agencles }(91.7)\end{array}$ & 3.20 & 3.16 & 3.21 & .069 \\
\hline $\begin{array}{l}\text { Including regular education teachers as equal partners in } \\
\text { planning and implementing programs for mainstreamed } \\
\text { pupils (91.0) }\end{array}$ & 3.66 & 3.08 & 3.75 & $9.244^{*}$ \\
\hline $\begin{array}{l}\text { Resolving conflicts by using strategies that minimize } \\
\text { "hard feelings" }(90.8)\end{array}$ & 3.53 & 3.36 & 3.24 & 2.022 \\
\hline $\begin{array}{l}\text { Using a planned sequence for problem solving in working } \\
\text { with regular education teachers on behatf of mainstreamed } \\
\text { pupils }(90.6)\end{array}$ & 3.03 & 2.92 & 3.28 & 3.327 \\
\hline $\begin{array}{l}\text { Probing to identify all the factors that contribute to a child's } \\
\text { problem, including those involving the regular education } \\
\text { teacher (89.9) }\end{array}$ & 3.35 & 3.02 & 3.21 & 2.677 \\
\hline $\begin{array}{l}\text { Obsenving mainstreamed leamers in regular education } \\
\text { classooms and other school settings (89.9) }\end{array}$ & 3.46 & 3.13 & 3.46 & 3.724 \\
\hline $\begin{array}{l}\text { Using specific strategles to facilitate interpersonal communi- } \\
\text { cation with regular education teachers }(88.1)\end{array}$ & 3.19 & 3.20 & 3.24 & .065 \\
\hline $\begin{array}{l}\text { Using a paraphrasing strategy to confrm the meaning of } \\
\text { regular education teachers' communications (83.1) }\end{array}$ & 3.58 & 3.28 & 3.37 & 2.555 \\
\hline $\begin{array}{l}\text { Conducting inservice training for regular education } \\
\text { teachers (79.5) }\end{array}$ & 2.50 & 2.42 & 2.65 & 1.016 \\
\hline
\end{tabular}

teachers (79.5)

astatements are shortened versions of those presented in questionnares.

bNumbers in parentheses represent the percentage of the total sample indicating the skill is needed by resource teachers.

${ }^{c}$ A 5-point rating scale was used on which $1=$ luttle skill, $3=$ some skill, and $5=$ much skill.

: $\mathrm{p}<.01$. 
school as the unit of analysis and professional role as the repeated measure, was used to ascertain whether the perceptions of resource teachers, regular education teachers, and principals differed.

Based on the summed scores, resource teachers and principals were found to be similar in their evaluations of resource teachers' skills $(\bar{X}=56.77$, $\mathrm{SD}=13.40$, and $56.82, \mathrm{SD}=11.74$, respectively, on a scale ranging from 17 to 85 ). Regular classroom teachers, however, rated resource teachers as being somewhat less skillful as consultants $(\bar{X}=51.60, S D=15.60)$. The difference among the groups was significant $[\mathrm{F}(2,250)=7.35$; $\mathrm{p}<.001]$.

When responses to each statement were examined separately, the pattern of similarity in resource teachers' and principals' responses was consistent, with regular classroom teachers typically assigning lower ratings (Table 1). Significant differences among the groups were found for four of the items: systematically evaluating interventions $[F(2,250)=5.56 ; p<.01]$; including teachers as equal partners in planning $[F(2,250)=13.57$; $\mathrm{p}<.001$ ]; regularly scheduling conferences with teachers $[F(2,250)=5.85 ; p<.01]$; and resource teachers explaining their perceptions of problem situations to teachers $[F(2,250)=9.24 ; p<.001]$.

\section{DISCUSSION}

The purposes of this investigation were to identify the consultation skills resource teachers are expected to possess, to determine their perceived level of competence as consultants, and to ascertain whether educators concur in their perceptions of this aspect of resource teaching. The resource teachers', regular education teachers', and principals' responses to a specially designed questionnaire provided information about each of these areas.

The educators surveyed believed that a wide variety of skills typically associated with consultation should be part of the resource teacher's repertoire. This finding raises important issues about the degree to which expectations for resource teacher job performance are realistic. Resource teachers appear to be expected to be "super teachers," that is, in addition to the primary responsibility of providing direct instruction to handicapped students, they are expected to confer with regular education teachers, observe students in mainstream settings, conduct inservice training, and so on, through a seemingly endless list of job duties. Given cur- rent time constraints, it is questionable, however, whether this tremendous range of tasks can be successfully managed by a single professional. If these educators' perceptions reflect the status quo, it is not surprising that resource teachers experience a high level of stress and burnout (Bensky, Shaw, Gouse, Bates, Dixon, \& Beame, 1980; Weiskopf, 1980).

The educators in this study judged resource teachers as moderately skilled in consultation. Although only tentative conclusions may be drawn on the basis of a single investigation, the findings suggest that teacher training needs to focus more on consultation, since a high skill level in this area is crucial for handicapped children's success in the mainstream. This conclusion is supported by other researchers. For example, although their findings indicated that regular educators viewed many resource teacher consultative services as unimportant, Speece and Mandell (1980) stressed that special educators should be trained to deal with such reluctance to collaborate in serving mainstreamed pupils. Similarly, Bauer (1975) referred to consultation as the most important though least discussed aspect of the resource teacher's job.

The differences in perceptions of competericy between resource teachers and principals, and regular education teachers may also be an indication that the consultation role warrants further attention. While recognizing the limits of self-report data, the findings suggest a number of questions: Why are regular education teachers less positive in their responses? Would resource teacher consultation training affect regular educators' perceptions, or do the latter group's responses reflect a general attitude toward handicapped students or mainstreaming? Alternatively, would an increase in resource teachers' time for consultation enable them to more satisfactorily meet regular educators' needs in this domain?

Continued study of the consulting role of resource teachers is essential. Although the results of the present investigation indicate that resource teachers are expected to consult and that they currently do so with moderate skill, further information is needed on how and when resource teachers fulfill their consulting responsibilities. Additionally, strategies for increasing resource teachers' effectiveness as consultants 
should be identified as a means of improving services for pupils and positively influencing classroom teachers' perceptions of resource teacher skill. Finally, examinations of the impact of increased resource teacher consultation on various groups of teachers and their pupils is necessary to determine the merit of recommending consultation as an integral part of the resource teacher's job.

\section{REFERENCES}

Bauer, $\mathrm{H}$. The resource teacher- $\mathrm{A}$ teacher consultant. Academic Therapy, 1975, 10, 299-304.

Bensky, J.M., Shaw, S.F., Gouse, A.S., Bates, N., Dixon, B., \& Beame, W.E. Public Law 94-142 and stress: A problem for educators. Exceptional Children, 1980, 47,24-29.

Brown, L.F., Kiraly, J., \& McKinnon, A. Resource rooms: Some aspects for special educators to ponder. Journal of Learning Disabilities, 1979, 12, 480-482.

Cohen, J. H. Handbook of resource room teaching. Rockville, MD: Aspen, 1982.

Elman, N.M., \& Ginsberg, J.W. The resource room primer. Englewood Cliffs, NJ: Prentice-Hall, 1981.

Evans, S. The consultant role of the resource teacher. Exceptional Children, 1980, 46, 402-404.

Evans, S. Perceptions of classroom teachers, principals, and resource room teachers of the actual and desired roles of the resource teacher. Journal of Learning Disabilities, 1981, 14, 600-603.

Gickling, E.E., Murphy, L.C., \& Mallory, D.W. Teachers' preferences for resource services. Exceptional Children, 1979, 45, 442-449.

Hawisher, M.F., \& Calhoun, M.L. The resource room. Columbus: Charles E. Merrill Publishing Company, 1978.

Heron, T. E., \& Harris, K. C. The educational consultant: Helping professionals, parents, and students. Boston: Allyn \& Bacon, 1982.

Hudson, F., Graham, S., \& Warner, M. Mainstreaming: An examination of the attitudes and needs of regular classroom teachers. Learning Disability Quarterly, 1979, 2(3), 58-62.

McLoughlin, J. A., \& Kelly, D. Issues facing resource teachers. Learning Disability Quarterly, 1982, 5, 58-64.

Paroz, J., Siegenthaler, L.S., \& Tatum, V.H. A model for a middle school resource room program. Journal of Learning Disabilities, 1977, 10, 7-15.

Sargent, L.R. Resource teacher time utilization: An observational study. Exceptional Children, 1981, 47, 420-425.

Speece, D.L., \& Mandell, C.J. Resource room support services for regular teachers. Learning Disability Quarterly, 1980, 3, 49-53.

Summers, D.E. The duties and responsibilities of the resource room teacher as perceived by regular classroom teachers, resource room teachers, and building principals (Doctoral dissertation, Ball State University, 1978). Dissertation Abstracts International, 1978, 39, 6073A-6074A. (University Microfilms No. 79-80, 451)

Weiskopf, P.E. Burnout among teachers of exceptional children. Exceptional Children, 1980, 47, 18-23.

Wiederholt, J.L., Hammill, D.D., \& Brown, V. The resource teacher: A guide to effective practices (2nd ed.) Boston: Allyn \& Bacon, Inc., 1983.

\section{FOOTNOTES}

'The resource teachers in rural school districts frequently served two, or even three schools. In some urban districts, however, several resource teachers were located in a single building. This accounts for the discrepancy between the number of resource teachers in the sample and the number of resource rooms used as the basis for the regular education samples.

Requests for reprints should be addressed to: Marilyn Friend, School of Education, University of Oklahoma, 820 Van Vleet, Norman, OK 73069. 